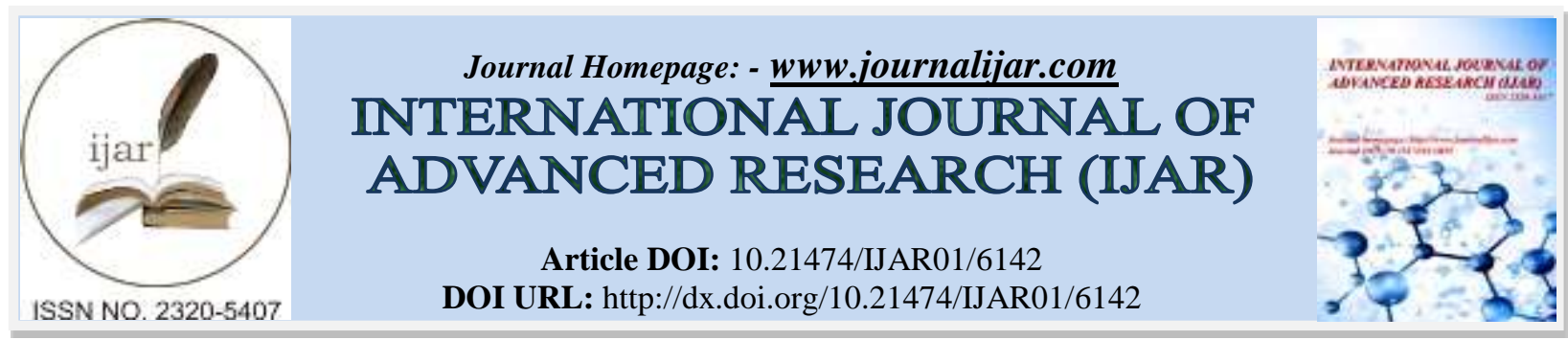

RESEARCH ARTICLE

\title{
CLIMATE CHANGES AND ITS IMPACT ON AGRICULTURE OF NORTHERN TELANGANA ZONE.
}

Mahesh Pallikonda.

M. Sc geography, osmania university, hyderabad, telangana, india.

\section{Manuscript Info}

Abstract

Manuscript History

Received: 23 October 2017

Final Accepted: 25 November 2017

Published: December 2017

Copy Right, IJAR, 2017,. All rights reserved.

\section{Introduction:-}

Climate change scenarios include higher temperatures, changes in precipitation, and higher atmospheric $\mathrm{CO} 2$ concentrations which may affect on yield (both quality and quantity), growth rates, photosynthesis and transpiration rates, moisture availability, through changes of water use (irrigation) and agricultural inputs such as herbicides, insecticides and fertilizers etc. Environmental effects such as frequency and intensity of soil drainage (leading to nitrogen leaching), soil erosion, land availability, reduction of crop diversity may also affect agricultural productivity.and its effect on Biodiversity.

Climate change is a change in the long-term weather patterns that characterize the regions of the world. The term "weather" refers to the short-term (daily) changes in temperature, wind, and/or precipitation of a region . In the long run, the climatic change could affect agriculture in several ways such as quantity and quality of crops in terms of productivity, growth rates, photosynthesis and transpiration rates, moisture availability etc. Climate change is likely to directly impact food production across the globe. Increase in the mean seasonal temperature can reduce the duration of many crops and hence reduce the yield. In areas where temperatures are already close to the physiological maxima for crops, warming will impact yields more immediately (IPCC, 2007). Drivers of climate change through alterations in atmospheric composition can also influence food production directly by its impacts on plant physiology. The consequences of agriculture's contribution to climate change, and of climate change's negative impact on agriculture, are severe which is projected to have a great impact on food production and may threaten the food security and hence, require special agricultural measures to combat. Climate change is any significant long-term change in the expected patterns of average weather of region (or the whole Earth) over a significant period of time. It is about non-normal variations to the climate, and the effects of these variations on other parts of the Earth. These changes may take tens, hundreds or perhaps millions of year. But increased in anthropogenic activities such as industrialization, urbanization, deforestation, agriculture, change in land use pattern etc. leads to emission of green house gases due to which the rate of climate change is much faster. Climate change scenarios include higher temperatures, changes in precipitation, and higher atmospheric $\mathrm{CO} 2$ concentrations. There are three ways in which the Greenhouse Effect may be important for agriculture. First, increased atmospheric $\mathrm{CO} 2$ concentrations can have a direct effect on the growth rate of crop plants and weeds. Secondly, CO2-induced changes of climate may alter levels of temperature, rainfall and sunshine that can influence plant and animal productivity. Finally, rises in sea level may lead to loss of farmland by inundation and increasing salinity of groundwater in 
coastal areas Agriculture is one of the critical areas vulnerable to Climate Change. Climate change in terms of rainfall variability is considered to be the greatest challenge. Both climate variability and change can lead to severe impacts on rainfed farming reducing yields and profitability.

The year to year variations in SouthWest monsoon rainfall are directly affecting the production and productivity of rain-fed crops in Telangana. Moisture stress due to prolonged dry spells or thermal stress due to heat wave conditions also significantly affect the crop productivity when they occur in critical life stages of the crop . About $55.49 \%$ of state's population in Telangana is dependent on agriculture \& allied sectors for their livelihoods. Agriculture in Telangana is dependent on rainfall. The average annual rainfall in the state is about $906 \mathrm{~mm}, 80$ percent of which is received from the South-West monsoon (AGRI. ACTION PLAN (2016 -17) of Telangana)

Aim and objectives of study:-

1. To Developing short-duration crop varieties that can mature before the peak heat phase set in.

2. Farmers can adapt to climate changes to some degree by shifting planting dates, choosing varieties with different growth duration, or changing crop rotations

3. To efficiency of water use, weather advisories to farmers, information on market prices etc.

4. To analysis various suitable agriculture techniques.

5. Find out environmentally suitable and economically affordable agriculture methods

6. To develop climate-resilient crop varieties that can tolerate higher temperatures, drought and salinity

7. .To study farmers problem and suggest solution to them.

8. Intensify the food production system by improving the technology and input delivery system.

9. To study various agriculture method in the study area.

\section{Study area:-}

The Northern Telangana semiarid zone lies between $17^{\circ} 42^{\prime}$ and $19^{\circ} 84^{\prime} \mathrm{N}$ Latitude ., and $77^{\circ} 38^{\prime}$ and $81^{\circ} 16^{\prime} \mathrm{E}$ Longitude . at 160 to $660 \mathrm{~m}$ above height . This zone includes the districts of Adilabad (Adilabad, Komurambhim, Manchiriala, Nirmal), Karimnagar (Karimnagar, Jagtial, peddapalli, Rajanna Siricilla), Nizamabad (Nizamabad, Kamareddy), with Regional Agricultural Research Station, Jagtial as Regional headquarters. The annual average rainfall is 900 to $1150 \mathrm{~mm}$ mostly from south-west monsoon. The maximum and minimum temperature during south-west monsoon ranges from $32^{\circ} \mathrm{C}$ to $37^{\circ} \mathrm{C}$ and $21^{\circ} \mathrm{C}$ to $25^{\circ} \mathrm{C}$ respectively. Red soils are predominant in the zone which includes chalkas, red sandy, deep red loamy and very deep black cotton soils are also seen in some parts of the zone. This zone has a total geographical area of 35.5 lakh ha. The climate is typically tropical rainy. The meanannual precipitation ranges from 900 to $1150 \mathrm{~mm}$ with 82 per cent of rainfall from south west monsoon. The net sownarea is $2.21 \mathrm{~m}$. ha. of which $0.67 \mathrm{~m}$. ha. is irrigated representing 30.3 per cent of the net sown area. The major crops grown in the zone are rice, sugarcane, jowar, pulses,maize, cotton, groundnut, turmeric and chillies and others.Cropping intensity is 110 per cent. Wells are the main source of irrigation followed by canals. Red chalka soils are predominant. Headquarter of northern telangana claimate zone is Jagtial(polasa). Important crop grown Rice, maize, soybean, cotton, redgram, turmeric.

Telangana State has been divided into four agro-climatic zones based on the geographical characteristics such as rainfall, nature of soils, climate etc. The agricultural planning for each zone is supported with the research and recommendations of Regional Agricultural Research Stations of PJTSAU setup within each zone. i) Northern Telangana Zone, (Adilabad, Nizambad and Karimnagar) ii) Central Telangana Zone, (Medak, Warangal and Khamam) iii) Southern Telangana Zone (Rangareddy Hyderabad, Nalgonda and Mahaboonagar) iv) High Altitude and Tribal Zone ( According to Telangana State Climate Change Circle ) 


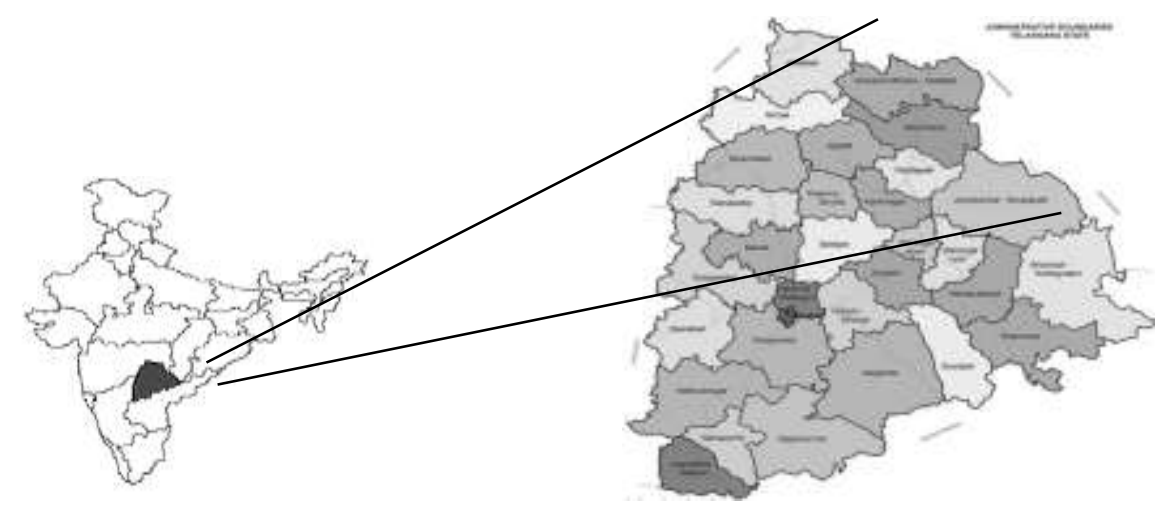

Coneptual Framework /Research Methodology

1. Book review and article review

2. collection of data:

Primary data: collection of primary data field work will be carried out. Physical factor like soil, water sample will be collected for study area.

Secondary data : collection through Agriculture Department, Agriculture Universities, Agriculture College, Government agencies, ICRISAT, various Government Websites like TSAPCC. Moefcc, http://ecostat.telangana.gov.in

3. Analysis of data - Study area map will be papered with the help of GIS software, questionnaires' will be prepared to take farmers interview, collected primary and secondary data will be assigned in Microsoft-Excel. Chart, Diagrams and tables will be prepared to represent data.

\section{Effects Of Climate Change On Agriculture Sector}

Key Issues-

Temperature fluctuations

Weather changes .

Changes in precipitation(Rainfall).

Higher atmospheric $\mathrm{CO}_{2}$ concentrations which leads to emission of green house gases

Effects on Biodiversity

\section{Research question of hypothesis:-}

1. climate changes impact on agriculture and food production,

2. Food security is both directly and indirectly linked with climate change.

3. Provide greater coverage of weather linked agriculture

4. Technology demonstration to help farmers cope with current climate variability

5. climate changes impact on agriculture and food production,

\section{Literature review:-}

Vandana Shiva (2016) has given vivid account of green revolution in her book entitled "Violence of Green Revolution". The present book is divided in seven chapter. This are based on science and politics, genetic diversity, soil fertility, water conflict, cultural coast biotechnology, technological changes. Writer expressed that during 1980 Asia has gone through cultural and ecological destruction. Writer has taken Panjab state for case study. Panjab is one of the rich state in India with high per capita income. Panjab crisis was mostly related to green revolution. Green revolution was decorated by ford foundation, world bank and Rockefeller to gain profit. Panjab crisis though it looks religious it has root in economics and politics. Panjab is one of the richest state in India with high per capita income and high grain production. Green revolution was considered as strategy of development in rural India but after two decades political, ecological and cultural coast of green revolution became visible. Reducing material has gave rise to political conflicts. Like colonization third world countries are fighting new colonization which is associated with biotechnology and their indigenous seeds. In 1970 Norman Borlaug was awarded for Nobel prize for his contribution for food and nutrition, it was known by the world as a miracle seed. It gave rise to green revolution. India is host country for the green revolution. Green revolution was flourished in Panjab but after two decades it is resulted in unfertile soil, water logged lands, crops with various diseases . 
According to A K Singh, deputy director-general (natural resource management) of the Indian Council of Agricultural Research (ICAR), medium-term climate change predictions have projected the likely reduction in crop yields due to climate change at between 4.5 and 9 per cent by 2039. The long run predictions paint a scarier picture with the crop yields anticipated to fall by 25 per or more by 2099 . With $27.5 \%$ of the population still below the poverty line, reducing vulnerability to the impacts of climate change is essential. Indian food production must increase by 5 million metric tons per year to keep pace with population increase and ensure food security. Coping with the impact of climate change on agriculture will require careful management of resources like soil, water and biodiversity. To cope with the impacts of climate change on agriculture and food production, India will need to act at the global, regional, national and local levels.

Anupama Mahato (2014) Climate Change and its Impact on Agriculture in this article The greenhouse effect is a natural process that plays a major part in shaping the earth's climate. It produces the relatively warm and hospitable environment near the earth's surface where humans and other life-forms have been able to develop and prosper. However, the increased level of greenhouse gases (GHGs) (carbon dioxide (CO2), water vapor (H2O), methane (CH4), nitrous oxide (N2O), hydrofluorocarbons (HFCs), perfluorocarbons (PFCs), and sulfur hexafluoride (SF6) etc) due to anthropogenic activities has contributed to an overall increase of the earth's temperature, leading to a global warming. The average global surface temperature have increased by $0.74 \mathrm{oC}$ since the late 19 th Century and is expected to increase by $1.4 \mathrm{oC}-5.8 \mathrm{oC}$ by $2100 \mathrm{AD}$ with significant regional variations (IPCC, 2007). The atmospheric $\mathrm{CO} 2$ concentration has increased from $280 \mathrm{ppm}$ to $395 \mathrm{ppm}$, CH4 concentration increased from 715 ppb to $1882 \mathrm{ppb}$ and $\mathrm{N} 2 \mathrm{O}$ concentration from $227 \mathrm{ppb}$ to $323 \mathrm{ppb}$ from the year 1750 and 2012. The Global Warming Potential (GWP) of these gases i.e, $\mathrm{CO} 2, \mathrm{CH} 4$ and $\mathrm{N} 2 \mathrm{O}$ are 1, 25 and 310 respectively, Corals in Indian Ocean will be soon exposed to summer temperatures that will exceed the thermal thresholds observed over the last 20 years. Annual bleaching of corals will become almost a certainty from 2050. Currently the districts of Jagatsinghpur and Kendrapara in Odisha; Nellore and Nagapattinam in Tamilnadu; and Junagadh and Porabandar districts in Gujarat are the most vulnerable to impacts of increased intensity and frequency of cyclones in India (NATCOM, 2004). The past observations on the mean sea level along the Indian coast show a long-term (100 year) rising trend of about $1.0 \mathrm{~mm} /$ year. However, the recent data suggests a rising trend of $2.5 \mathrm{~mm} /$ year in sea level along Indian coastline. The sea surface temperature adjoining India is likely to warm up by about $1.5-2.0 \mathrm{oC}$ by the middle of this century and by about $2.5-3.5 \mathrm{oC}$ by the end of the century. A 1 meter sea-level rise is projected to displace approximately 7.1 million people in India and about $5764 \mathrm{sq} \mathrm{km}$ of land area will be lost, along with $4200 \mathrm{~km}$ of roads (NATCOM, 2004). Over $50 \%$ of India's forests are likely to experience shift in forest types, adversely impacting associated biodiversity, regional climate dynamics as well as livelihoods based on forest products. Even in a relatively short span of about 50 years, most of the forest biomass in India seems to be highly vulnerable to the projected change in climate.

The comprehensive work on history of Agriculture Geography has been carried out by Alka Gautam (2012). She described as Agriculture geography is one of the most important branch of Human Geography, previously it was studied under economic geography. During the second world war great destruction made world pathetic. The world war was resulted in Great depression in 1920 and food scarcity. This situation moved scientist from technology research to agriculture research. Since that time agriculture geography is flourished, before that agriculture was noted by Arab Geographer, Indian geographer and Chinese geographer but never studied in detail, they just explained cropping pattern and dominant crops in the world. Arthur young 1770 produced first book in agriculture geographer. Humboldt a visionary geographer visited many places in the world and he wrote first scientific book using regional approach and inductive method called "Land Use in Cuba and South America" (1807). Schwenz (1816) gave first account of spatial distribution of crops. Agriculture regionalization was made by Jonsson (1926).

the mixture of Bordeaux. Sustainable agriculture is conservation of non-renewable resources like soil, water, energy and minerals but also issues environment, economic and social sustainability. Canadian farmer adopted organic farming for profit. stolze explain that regulation of inputs and outcome of environmental or resources use. soil association 1990 stated that avoidance of soluble mineral salt and prohibition of agrochemical pesticides are two major characteristics of organic farming. Energy and thermodynamics has played important role development ecological economics as stated by Costanza 1991.

C. Subrahmanyam agriculture minister 1965 and M.S Swaminathan the director of IARI 1965 are the main supporter of green revolution in India. They were trained by Norman Borlaug who worked for Rockefeller agricultural program in Mexico. First time rice seed was brought to India from international Rice Research Institute. 
Late prime minister Lal Bhahdur Shastri raised question against new verity but his death in 1966 made its entry easy. Intensive agriculture program was launched for selective villages and indigenous crop was chosen but they didn't perform well like modified crops because they are not made to consume high nutrition. Green revolution has impacted on economy, environment, socity and politics. It has badly impacted on farmer and destroyed village economy. Multinational company has encroached peasants money and made their life more pathetic.

Carine Pionetti and Reddy S. (2002) assessed the diversity on Deccan Plateau with special reference to Maharashtra, Telangana and Karnataka Plateau. They mainly concentrated on soil and water qualities. They analyzed soil type, thickness of soil, water holding capacity and crop diversity techniques It has poor soil. So, it need some strategy to improvement. Biodiversity conservation, cropping strategies. Almost two third of Indian farmers practice rainfed agriculture. Fragmented land holding is one more problem of the marginal farmers. Rainfall is low in semi-arid Deccan Plateau. Seasonal migration is necessary in semi-arid region to deal with this climatic condition. Crop diversity technic followed in Medak district by women to alleviate food scarcity. Red soil and black soil are common soil on Deccan Plateau, compare to black soil red soil is less fertile. Red soil is suitable to shallow root system, it has low water holding capacity so crops like pearl millet, little millet, sorghum, Niger grown in Kharif (rainy) season. Black soil is fertile soil so it can host two crops a year in kharif and rabbi season.

They came to the conclusion that mixed cropping system is useful for pest control. Farmers takes ginger and turmeric crop and plants castor for protection from disease and provide shade. Crop combination is also one of the technique in which they suggested natural pest control such as wheat and chickpea crop combination to protect wheat from rat. Crops growing period is also important, marginal farmers takes early maturing verity with main crop. Sorghum, Kakimuttani Jonna and black gram grows early and less suffer by scarcity of water. Deccan plateau is rich in biodiversity so lots of verity of sorghum, millets, pigeon pea, groundnut, sugarcane and mongo. Shamsuddinapur village women produced local seeds. Farmers should take into consideration the qualities like highly ranked seed test, early maturity and capacity to withstand to late rain.

Soil and water quality issues vis- a- vis agriculture management practice in Deccan plateau is studied by Sahrawat K.L, Murugappan at all. (2006). They focused on proper strategy to improve agriculture on Deccan plateau. Mining and erosion are major problem associated with soil. Agriculture productivity should not effect on soil quality. The main aim of the paper is to find out impact of agriculture practice on soil and water quality. Soil quality management and crop selection is very useful for sustainable development. They have explained water holding capacity, bulk density, total porosity, air filled porosity, hydraulic conductivity, crusting sealing and soil depth are greatly influenced on root development of crops. According to VijayaLaxmi 1987 Soil erosion offered poor root growth. Several land treatments like contour bunds, field bunds, graded bunds have been evaluated for soil and water conservation in the red soil on Deccan plateau. According to Hegade (1987) small land holding and community work restrict the soil and water conservation efforts. The article gave evidence of the study conducted by ICRISAT for 23 year in the field shows that management in practices given positive changes in physical property of soil like Porosity, Bulk density, penetration resistant was lower and air filled porosity was higher. Even study of two soil of different texture in Hyderabad shown application of pearl millet has improved physical property of soil. Soil loss has impact on not only on soil quality but also water quality (Sahrawat et al). according to kurothe et al 2001 contour cultivation, contour bunds, graded bunds, Nala building, checkdams and farm pond to achieve higher production in the area. Integrated project of ICRISAT and Telangana Rural livelihood project they found that Deccan Plateau region is more suitable for cereal production. Earthworm distribution is more in undisturbed area than cultivated area and earthworm number was decreased due to carbofuran insecticide and herbicide was noted by Reddy in 1995. article explain about water quality by clarity, sediment, dissolved solid and organic and inorganic material. Even chemical property like salinity, aikinite, dissolved oxygen, nitrate, prosperous, heavy metal, pesticide another toxic compound. Panjab agriculture university has shown in Ludhiana that high fertilizer use has leads to more concentration of nitrate in water. The given article is precise information about importance of water and soil in agriculture. It explains its pollution, causes and impact on the production. In the same article, they have suggested various finding how to tackle problem like erosion, pollution, conservation. So, overall It concludes that the given article is full estimation on soil and water. Agriculture production is depended on soil quality and water quality.

Carrol and Risch has been given different approach of sustainable development, are integrated crop management, low input agriculture, low input sustainable agriculture, agroecology, permaculture, biodynamic farming. This method was developed by many scientists. Authorities states that aim of farming is create integrated human, environmentally and economically sustainable development system. Which maximize renewable resources and 
biological and ecological process and interaction. To provide acceptable crop production, livestock, human nutrition, protection from pest and diseases and appropriate return to human and other resources. Organic farming is a similar world to sustainable agriculture but some says it is a misleading concept. Nitrate losses, soil erosion is major problem of agriculture. Pretty explain that organic farming has negative impact as leaching of nitrates from the field of legumes, Land degradation has resulted in decrease in cultivation area, low productivity of livestock. Finally, they concluded that Land degradation can be controlled by soil conservation, better management of grazing system and protection of sensitive area. It can be done by understanding its cause impact and degree and its acquaintances with climate, water, land cover and social economic factor. Here need to prepare strategy for mixed crop livestock system, grazing land, woodlands, soil management.

Above research are contemporary research. They are dealing with new techniques in agriculture. Its shows the recent trend in agriculture. So, the study of recent trends in agriculture is useful to find solution to the framer's problem by finding out the best agriculture techniques and method, which are affordable, environment friendly and economically profitable.

\section{Scope of methodology:-}

In India there is different types of farming exist. Selecting genotype in crops that have a higher per day yield potential to counter yield loss from heat-induced reduction in growing periods. Efficient water use such as frequent but shallow irrigation, drip and sprinkler irrigation for high value crops, irrigation at critical stages These innovative methods will be studied. It will help to farmer to spread their knowledge to other farmers. Field study will be carried out to know actual situation of this methods. Soil samples will be collected from the farm. Tahsil wise data will be collected from tehsil office from the study area. Statistical method will be used to find profit from these methods. Study area map will be used to show the distribution of physiography, climate, soil and crop distribution in the study area. Final conclusion will be shown with help of pie diagrams, charts, bar diagrams. Tables will be made to show calculation of the data.

\section{Relevance of anticipated outcomes:-}

1. Participatory and formal plant breeding to develop climate-resilient crop varieties that can tolerate higher temperatures, drought and salinity.

2. To know efficient water use such as frequent but shallow irrigation, drip and sprinkler irrigation for high value crops, irrigation at critical stages.

3. To know Seasonal weather forecasts could be used as a supportive measure to optimize planting and irrigation patterns.

4. Environment friendly method.

5. Economically affordable.

\section{Proposed outcomes from the research:-}

Guide to farmers to obtain Low input method with More output.

Developing short-duration crop varieties.

suggest to the Farmers can adapt to climate changes and they shifting planting dates and changing crop rotations. Selecting genotype in crops that have a higher per day yield potential to counter yield loss from heat-induced reduction in growing periods.

Suggest environment friendly method for sustainable developmen.

\section{Conclusion:-}

Climate change, the outcome of the "Global Warming" has now started showing its impacts worldwide. Climate is the primary determinant of agricultural productivity which directly impact on food production across the globe. Agriculture sector is the most sensitive sector to the climate changes because the climate of a region/country determines the nature and characteristics of vegetation and crops. Increase in the mean seasonal temperature can reduce the duration of many crops and hence reduce final yield. Food production systems are extremely sensitive to climate changes like changes in temperature and precipitation, which may lead to outbreaks of pests and diseases thereby reducing harvest ultimately affecting the food security of the country. The net impact of food security will depend on the exposure to global environmental change and the capacity to cope with and recover from global environmental change. Coping with the impact of climate change on agriculture will require careful management of resources like soil, water and biodiversity. To cope with the impact of climate change on agriculture and food production. 


\section{References:-}

Books

1. Vandana Shiva (2016), "Violence of Green revolution third world Agriculture, Ecology and Politics", University press of Kentucky

2. Zeba Siddiqui ( 2009 ) "Agricultural Geography Marketing and Development" Published by Rajat Publications

3. Goutam Alka (2012), “Agriculture Geography”, Sharada Pustak Bhawan, Allahabad.

Articles

1. Dr. I. V. SUBBA RAO (1989), "Northern Telangana Region”.

2. Anupama Mahato (2014), "Climate Change and its Impact on Agriculture"

3. Carine Pionetti and Reddy S., (2008), "Diversity on Deccan Plateau" Grain Publication,2008.

4. Ahmad, J., Alam, D., \& Hassen, S., Impact of Climate Change on Agriculture \& Food Security in India, : 131136

5. Sahrawat K.L, Murugappan at all. (2006), "Soil and water quality issues vis- a- vis agriculture management practice in Deccan plateau", Indian Society of Soil Science, January 2006.

6. Marthe Kiley- Worthington (2014), "Ecological agriculture. Integrating low input high productive farming with wildlife conservation", Scientific journal, open journal of ecology 2014. Websites

1. TSAPCC- http://www.moef.gov.in/sites/default/files/Telangana.pdf

2. AGRICULTURE ACTION PLAN (2016 to 17) by DEPARTMENT OFAGRICULTUREhttp://agri.telangana.gov.in/open_record_view.php?ID=119 